\title{
Successful rituximab treatment of granulomatosis with polyangiitis with cranial neuropathies
}

\author{
Maho Nakazawa, Katsuya Suzuki, Hidekata Yasuoka, Kunihiro Yamaoka and Tsutomu Takeuchi*
}

\begin{abstract}
Background: In granulomatosis with polyangiitis (GPA), peripheral nerve involvement is common but central nervous system (CNS) involvement is extremely rare and treatment strategy has not been established. We report a case of intravenous cyclophosphamide (IVCY)-resistant GPA with associated cranial neuropathies that was successfully treated with rituximab (RTX).

Case presentation: A 37-year-old man with intractable sinusitis had several months of headache, hoarseness, and dysphagia; a month of right-sided deafness and nasal bleeding; and a week of dysarthria, steppage gait, and numbness in the right L5 distribution. A magnetic resonance imaging (MRI) examination of the head showed an infiltrative lesion in the right skull base encasing the carotid sheath. Computed tomography (CT) scan of the chest revealed a $23 \mathrm{~mm}$ nodule in the left upper lobe. Histology was inconclusive. Therefore, the patient was diagnosed as GPA. He was treated with glucocorticoids (GC) and IVCY. Three months later, he was readmitted for recurrence of headache and new left-sided hearing loss. He was treated with GC and RTX, and a 1-year remission followed. The molecular mechanism of RTX is not fully understood. In this case, RTX was more effective at rapidly and strongly suppressing B cells than CY. Since the B cell count was proportional to the patient's clinical manifestations, B cells might represent a suitable target for the treatment of GPA with cranial neuropathies.
\end{abstract}

Conclusions: GPA with cranial neuropathies might be useful with RTX as induction therapy.

Keywords: Granulomatosis with polyangiitis, Cranial neuropathies, Rituximab, Drug resistance, B-lymphocytes

\section{Background}

Granulomatosis with polyangiitis (GPA) is a systemic necrotizing granulomatous vasculitis that involves the upper airways, lungs, and kidneys. While peripheral nerve involvement is common, central nervous system (CNS) involvement is extremely rare $[1,2]$. We report the successful treatment of a case of cyclophosphamide (CY)-resistant GPA with cranial neuropathies with rituximab.

\section{Case presentation}

A 37-year-old man was admitted to hospital for several months of headache, hoarseness and dysphagia; a month of right-sided deafness and nasal bleeding; and a week of dysarthria. He had experienced sinusitis for 1 year before

\footnotetext{
* Correspondence: tsutake@z5.keio.jp

Division of Rheumatology, Department of Internal Medicine, Keio University School of Medicine, 35 Shinanomachi, Shinjuku-ku, Tokyo, Japan
}

admission and had been treated with antibiotics. He was successfully treated with glucocorticoids (GC) for sudden right-sided hearing loss 9 months before admission. His body weight had decreased by $10 \mathrm{~kg}$ over the previous month. A week before admission, he developed a right steppage gait and numbness in the right L5 distribution.

On admission, body temperature was $37.7^{\circ} \mathrm{C}$ and the rest of his vital signs were normal. Neurological examination showed a bilateral mixed hearing loss, a right curtain sign, weakness of the right trapezius, rightward tongue deviation, and paralysis of the right peroneal nerve. Initial blood tests showed a slightly elevated erythrocyte sedimentation rate $(29 \mathrm{~mm} / \mathrm{h})$ and C-reactive protein (CRP) levels $(1.06 \mathrm{mg} / \mathrm{dL})$, and white blood cell count was slightly increased $(8.9 \times 109 / \mathrm{L})$. His renal and liver function was normal (eGFR $118 \mathrm{ml} /$ minute $/ 1.73 \mathrm{~m} 2$ ) and the urine test was also normal (proteinuria, hematuria, urinary cast were negative). Anti-nuclear

(c) The Author(s). 2018 Open Access This article is distributed under the terms of the Creative Commons Attribution 4.0 International License (http://creativecommons.org/licenses/by/4.0/), which permits unrestricted use, distribution, and reproduction in any medium, provided you give appropriate credit to the original author(s) and the source, provide a link to the Creative Commons license, and indicate if changes were made. The Creative Commons Public Domain Dedication waiver (http://creativecommons.org/publicdomain/zero/1.0/) applies to the data made available in this article, unless otherwise stated. 
antibody, rheumatoid factor, angiotensin converting enzyme, myeloperoxidase-anti-neutrophil cytoplasmic antibody and soluble interleukin-2 receptor were normal, but proteinase 3-anti-neutrophil cytoplasmic antibody was increased $(16.9 \mathrm{IU} / \mathrm{mL})$. Cerebrospinal fluid was normal. A gadolinium-enhanced MRI scan of the head showed an enhancing infiltrative lesion in the right retropharynx encasing the carotid sheath (Fig. 1a), which seemed to cause the paralysis of IX, $\mathrm{X}, \mathrm{XI}$ and XII nerves. Lumber spine MRI showed no evidence of lumbar disk herniation and nerve conduction study showed the paralysis of the right peroneal nerve. Chest computed tomography showed a $23 \mathrm{~mm}$ nodule in the left upper lobe. A CT-guided needle biopsy of the lung lesion and biopsy of the nasal mucosa were performed but showed only infiltration of inflammatory cells and no evidence of malignancy, vasculitis or granuloma. Culture of the lung specimen showed no evidence of infection and the interferon-gamma release assay for Mycobacterium tuberculosis was negative. We diagnosed GPA based on the American College of Rheumatology classification criteria for Wegener's granulomatosis (WG) and classification of WG by the Watts algorism [3, 4].
The patient was treated with prednisone (PSL) $1 \mathrm{mg} / \mathrm{kg}$ daily and IVCY $1000 \mathrm{mg}$ every 3 weeks (Fig. 2). His fever, headache, and swallowing function improved rapidly, and peripheral neuropathy also improved, but hoarseness persisted. His Birmingham Vasculitis Activity Score 2008 version 3 score improved from 14 to 4 , and he was discharged on IVCY and a tapering dose of PSL $45 \mathrm{mg} /$ day [5].

Three months later, while receiving oral GC and IVCY, he was readmitted for recurrence of headache and right-sided hearing loss. On MRI, the lesion encasing the right carotid sheath has not reduced (Fig. 1b). CRP levels remained slightly increased $(1.04 \mathrm{mg} / \mathrm{dL})$. He was treated with RTX $600 \mathrm{mg} /$ week for 4 weeks and GC for re-induction therapy. His headache improved rapidly and hearing ability improved slowly. He was still on GC 1 year after RTX administration, with persistent hoarseness as his only symptom.

To investigate immune status, we tracked peripheral $\mathrm{T}$ and B cell counts after RTX administration (Fig. 3). According to the peripheral $\mathrm{T}$ and $\mathrm{B}$ cell counts, whereas $\mathrm{CY}$ treatment with $\mathrm{GC}$ reduced the number of peripheral CD4+ and CD8+ T cells and B cells, RTX selectively

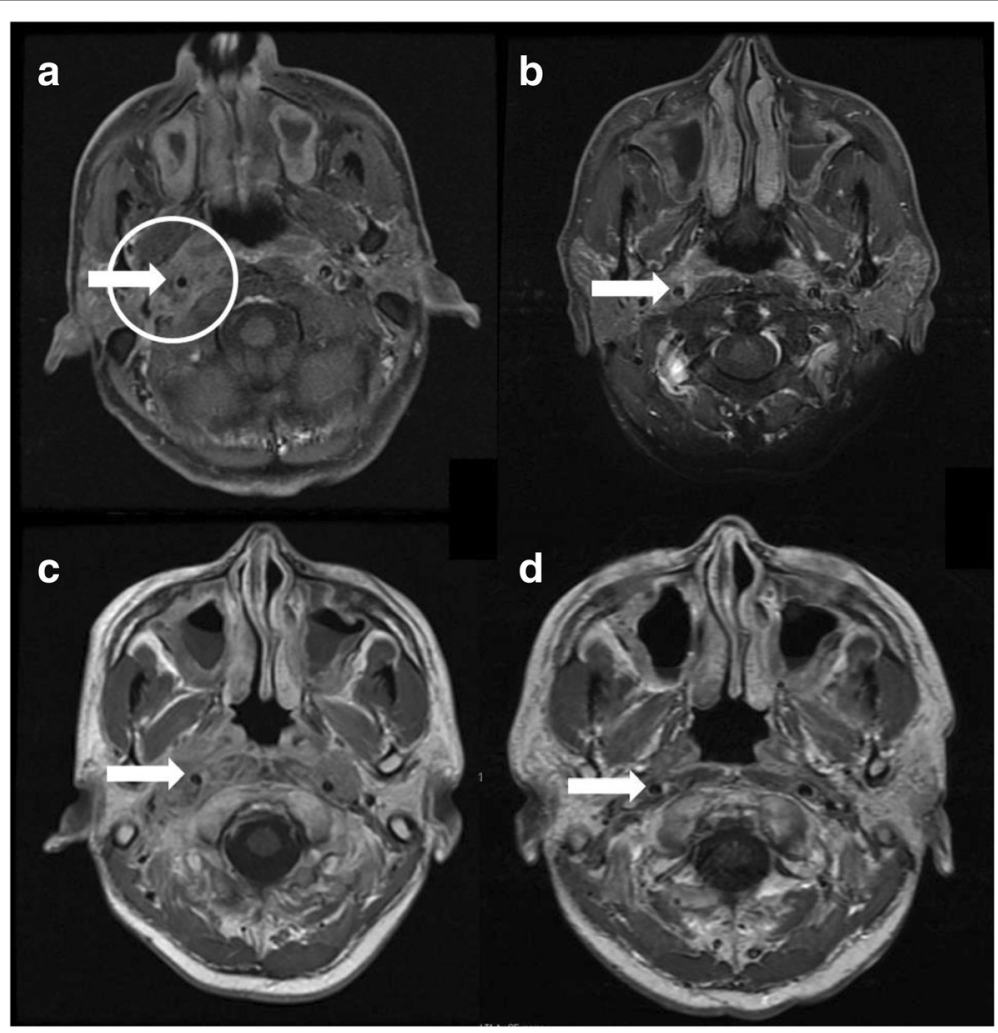

Fig. 1 Magnetic Resonance (MR) imaging of the head. Fat-suppressed T1-weighted gadolinium-enhanced axial scans through the skull base $(\mathbf{a}, \mathbf{b})$, and T1-weighted gadolinium-enhanced axial scans of the skull base $(\mathbf{c}, \mathbf{d})$. There is bilateral maxillary sinusitis and an infiltrative lesion of the right retropharynx (circle) around the internal carotid artery (arrow). Images were taken a on admission, $\mathbf{b}$ after the 1st IVCY, $\mathbf{c}$ before RTX treatment, and (d) 6 months after RTX treatment. (d) The sinusitis and the infiltrative lesion were markedly improved after RTX treatment 


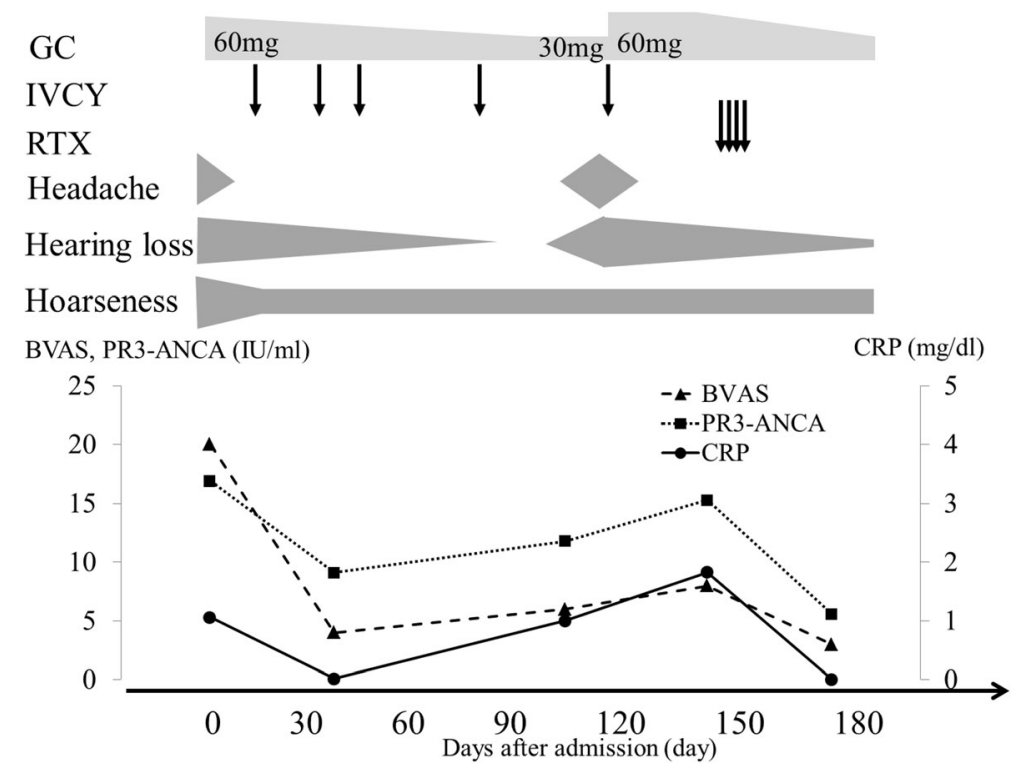

Fig. 2 Clinical course. IVCY dose and interval were 1000 mg every 3 weeks and RTX dose and interval were 600 mg every week. GC, glucocorticoid; IVCY, intravenous cyclophosphamide; RTX, rituximab; BVAS, Birmingham Vasculitis Activity Score 2008 version 3; PR3-ANCA, proteinase 3-anti-neutrophil cytoplasmic antibody; CRP, C-reactive protein

reduced the number of peripheral $B$ cells slowly over time. B cells tended to decrease 2 weeks after RTX treatment, with the reduction lasting 8 months.

\section{Discussion and conclusions}

We encountered a case of GPA with lower cranial and peripheral neuropathies. Although GPA often displays neurological involvements, they are mostly peripheral neuropathies and cranial neuropathies are extremely rare. Among cranial neuropathies, optic nerve neuropathy is the most common [6]. The pathogenesis of cranial neuropathies is still unclear because biopsy of the lesion is difficult and risky. It is unclear whether cranial neuropathies arise due to mechanisms of vasculitis or granuloma formation.

We used the PubMed database to retrieve all articles written in English containing the descriptors GPA and cranial neuropathy in their titles or texts, including treatment regimen. The nine known cases of GPA with cranial nerve involvement are listed according to treatment in Table 1 [6-13]. Similar to our case, most cases

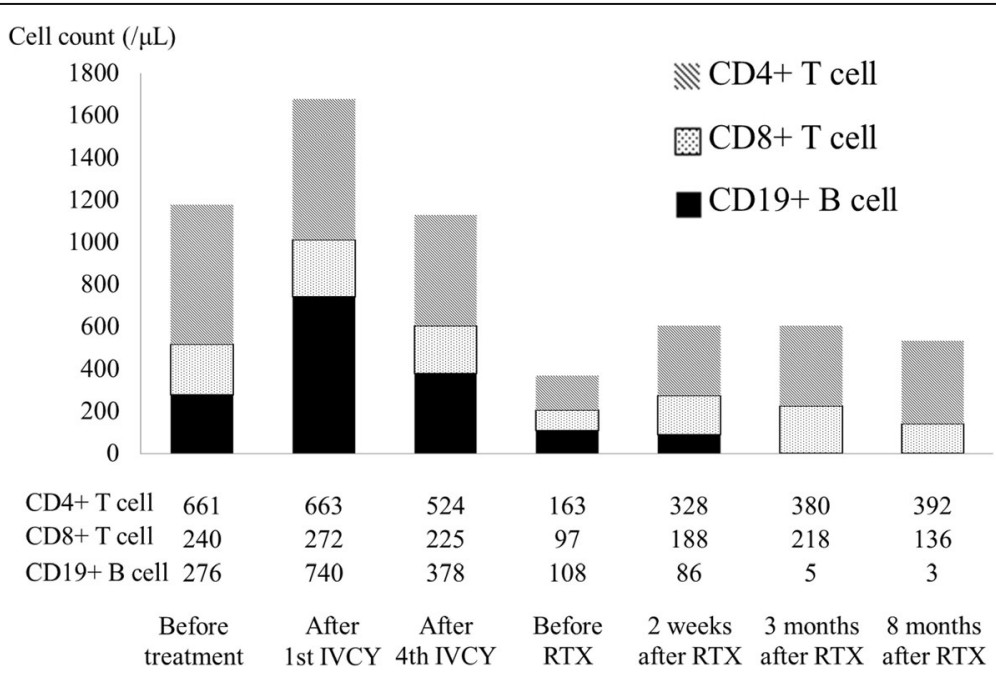

Fig. 3 Changes in peripheral lymphocyte count. CD4, CD4+ T cell; CD8, CD8+ T cell; CD19, CD19+ B cell 
Table 1 Reported cases of GPA with cranial neuropathies

\begin{tabular}{|c|c|c|c|c|c|c|}
\hline Reference & Age and sex & Signs and symptoms & $\begin{array}{l}\text { Cranial nerve } \\
\text { involvement }\end{array}$ & MRI findings & $\begin{array}{l}\text { Treatment for } \\
\text { induction }\end{array}$ & Outcome \\
\hline [7] & $23 \mathrm{~F}$ & Otalgia, facial paralysis, dysphagia & $\mathrm{V}, \mathrm{IX}, \mathrm{X}$ & $\begin{array}{l}\text { Mass on right skull base encasing } \\
\text { the carotid sheath }\end{array}$ & $\mathrm{GC}+\mathrm{CY}$ & $\begin{array}{l}\text { No recurrence } \\
\text { for } 1 \text { year }\end{array}$ \\
\hline [8] & $42 \mathrm{~F}$ & $\begin{array}{l}\text { Dysphagia, paresis of fifth nerve, } \\
\text { genioglossus, trapezius, } \\
\text { and sternocleidomastoid }\end{array}$ & $\begin{array}{l}\text { V, IX, X, XI, } \\
\text { XII }\end{array}$ & Normal & $\mathrm{GC}+$ oral $\mathrm{CY}$ & $\begin{array}{l}\text { No recurrence } \\
\text { for } 30 \text { months }\end{array}$ \\
\hline [6] & $73 \mathrm{~F}$ & $\begin{array}{l}\text { Dysarthria, left hearing loss, } \\
\text { paresis of hypoglossal nerve }\end{array}$ & VIII, IX, X, XII & $\begin{array}{l}\text { Mass on left skull base encasing } \\
\text { the internal carotid artery }\end{array}$ & $\begin{array}{l}\mathrm{GC}+\text { intravenous } \\
\mathrm{CY}\end{array}$ & $\begin{array}{l}\text { Failure for } \\
\text { re-induction }\end{array}$ \\
\hline [9] & $35 \mathrm{M}$ & $\begin{array}{l}\text { Dysphagia, paresis of vagus } \\
\text { and accessory nerve }\end{array}$ & $X, X I$ & Not performed (brain CT was normal) & $\mathrm{GC}+\mathrm{CY}$ & $\begin{array}{l}\text { No recurrence } \\
\text { for } 6 \text { months }\end{array}$ \\
\hline [10] & $30 \mathrm{~F}$ & $\begin{array}{l}\text { Dysarthria, paresis of } \\
\text { hypoglossal nerve }\end{array}$ & XII & $\begin{array}{l}\text { Right-sided retropharyngeal } \\
\text { mass effacing the carotid sheath }\end{array}$ & $\mathrm{GC}+\mathrm{MTX}$ & Not described \\
\hline [11] & $42 \mathrm{M}$ & Hearing loss, facial nerve palsy & VII, VIII & Not described & $\mathrm{GC}+$ oral $\mathrm{CY}$ & $\begin{array}{l}\text { Failure for } \\
\text { re-induction }\end{array}$ \\
\hline [12] & $69 M$ & Diplopia & $\mathrm{VI}$ & Normal & $\mathrm{GC}+$ oral $\mathrm{CY}$ & $\begin{array}{l}\text { No recurrence } \\
\text { for } 4 \text { months }\end{array}$ \\
\hline [12] & $31 \mathrm{~F}$ & $\begin{array}{l}\text { Hoarseness, dysphagia, hypoglossal } \\
\text { nerve and abducens nerve palsies }\end{array}$ & $\mathrm{VI}, \mathrm{X}, \mathrm{XI}, \mathrm{XII}$ & Normal & $\mathrm{GC}+\mathrm{CY}$ & Not described \\
\hline [13] & $56 \mathrm{~F}$ & Facial palsy and hearing loss & VII, VIII & $\begin{array}{l}\text { Mass on central and posterior skull base } \\
\text { adjoinin the clivus and jugular foramen }\end{array}$ & $\mathrm{GC}$ & Not described \\
\hline
\end{tabular}

GC glucocorticoid, MTX methotrexate; $C Y$ cyclophosphamide

with lower cranial neuropathies had MRI findings of a unilateral skull base process encasing the carotid sheath. The inflammation of upper respiratory tract lesion might progress posteriorly and extend into the retropharyngeal space. Recently, RTX was shown to be effective for treating anti-neutrophil cytoplasmic antibody-positive GPA and microscopic polyangitits. (RAVE study) [14]. However, the effectiveness of RTX in CNS involvement was not evident in the study. Most previous case reports have treated patients with $\mathrm{CY}$ for induction therapy, with few receiving GC monotherapy or methotrexate. One patient who was treated with $\mathrm{CY}$ had a recurrence and then RTX for re-induction therapy was effective, but long term effectiveness was not shown [6]. The present case is the second case to show the efficacy of RTX in refractory GPA with cranial neuropathies, which induces remission for 1 year.

Another study that demonstrated the efficacy of RTX in refractory GPA showed complete remission/improvement in $89.2 \%$ of patients with renal disease and $80.8 \%$ with alveolar hemorrhage, but only $44.4 \%$ of those with orbital masses and $49.9 \%$ with pachymeningitis [15], suggesting that RTX may be more effective for vasculitic than granulomatous manifestations. While involvement of granulomatous regions was suspected in this cranial neuropathy case [7], RTX was successfully effective. Further case series study would be needed.

The molecular mechanism of RTX is not fully understood. We speculated that RTX was more effective at rapidly and completely suppressing $B$ cells than
CY (Fig. 3). Since B cell count was proportional to the clinical manifestations, B cells might represent a good target for the treatment of GPA with cranial neuropathies. In these cases, rapid suppression of $B$ cells by RTX might be critical.

In conclusions, GPA with cranial neuropathies might be effective with RTX as induction therapy.

\section{Abbreviations}

CNS: central nervous system; CRP: C-reactive protein; CT: computed tomography; GC: glucocorticoids; GPA: granulomatosis with polyangiitis; IVCY: intravenous cyclophosphamide; IVCY: intravenous cyclophosphamide; MRI: magnetic resonance imaging; PSL: prednisone; RTX: rituximab; WG: Wegener's granulomatosis

Funding

Not applicable.

\section{Availability of data and materials}

Data sharing is not applicable to this article as no datasets were generated or analyzed during the current study.

\section{Authors' contributions}

MN wrote this manuscript. All authors revised the manuscript.

Ethics approval and consent to participate

Not applicable.

\section{Consent for publication}

Written informed consent was obtained from the patient for publication of the report.

\section{Competing interests}

The authors declare that they have no competing interests.

\section{Publisher's Note}

Springer Nature remains neutral with regard to jurisdictional claims in published maps and institutional affiliations. 
Received: 10 June 2018 Accepted: 20 July 2018

Published online: 19 November 2018

\section{References}

1. Nishino H, Rubino FA, DeRemee RA, Swanson JW, Parisi JE. Neurological involvement in Wegener's granulomatosis: an analysis of 324 consecutive patients at the Mayo Clinic. Ann Neurol. 1993;33:4-9.

2. Burlacoff SG, Wong FS. Wegener's granulomatosis. The great masquerade: a clinical presentation and literature review. J Otolaryngol. 1993;22:94-105.

3. Leavitt RY, Fauci AS, Bloch DA, Michel BA, Hunder GG, Arend WP, et al. The American College of Rheumatology 1990 criteria for the classification of Wegener's granulomatosis. Arthritis \& Rheumatism. 1990;33:1101-7.

4. Watts R, Lane $S$, Hanslik T, Hauser T, Hellmich B, Koldingsnes W, et al. Development and validation of a consensus methodology for the classification of the ANCA-associated vasculitides and polyarteritis nodosa for epidemiological studies. Ann Rheum Dis. 2007;60(2):222-7.

5. Mukhtyar C, Lee R, Brown D, Carruthers D, Dasgupta B, Dubey S, et al. Modification and validation of the Birmingham Vasculitis activity score (version 3). Ann Rheum Dis. 2009;68:1827-32.

6. Söderström A, Revaz S, Dudler J. Cranial neuropathies in granulomatosis with polyangiitis (Wegener's): a case-based review. Clin Rheumatol. 2015;34: 591-6.

7. Keni SP, Wiley EL, Dutra JC, Mellott AL, Barr WG, Altman KW. Skull base Wegener's granulomatosis resulting in multiple cranial neuropathies. Am J Otolaryngol. 2005;26:146-9.

8. Armani M, Spinazzi M, Andrigo C, Fassina A, Mantovan M, Tavolato B. Severe dysphagia in lower cranial nerve involvement as the initial symptom of Wegener's granulomatosis. J Neurol Sci. 2007;263:187-90.

9. Loke YK, Tan MH. An unusual case of Wegener's granulomatosis. Med J Malays. 1998;53:107-9.

10. Finley JC Jr, Bloom DC, Thiringer JK. Wegener granulomatosis presenting as an infiltrative retropharyngeal mass with syncope and hypoglossal paresis. Arch Otolaryngol Head Neck Surg. 2004;130:361-5.

11. Fujikawa K, Kawakami A, Eguchi K. Recovery from multiple cranial nerve palsy of Wegener's granulomatosis with infliximab. J Rheumatol. 2008;35: 1471-2.

12. Nowack R, Wachtler P, Kunz J, Rasmussen N. Cranial nerve palsy in Wegener's granulomatosis—lessons from clinical cases. J Neurol. 2009;256 299-304.

13. Sharma A, Deshmukh S, Shaikh A, Dabholkar J. Wegener's granulomatosis mimicking skull base osteomyelitis. J Laryngol Otol. 2012;126:203-6.

14. Stone JH, Merkel PA, Spiera R, Seo P, Langford CA, Hoffman GS, et al. RAVEITN research group. Rituximab versus cyclophosphamide for ANCAassociated Vasculitis. N Engl J Med. 2010;363:221-32.

15. Holle JU, Dubrau C, Herlyn K, Heller M, Ambrosch P, Noelle B, et al. Rituximab for refractory granulomatosis with polyangiitis (Wegener's granulomatosis): comparison of efficacy in granulomatous versus vasculitic manifestations. Ann Rheum Dis. 2012;71:327-33.

Ready to submit your research? Choose BMC and benefit from:

- fast, convenient online submission

- thorough peer review by experienced researchers in your field

- rapid publication on acceptance

- support for research data, including large and complex data types

- gold Open Access which fosters wider collaboration and increased citations

- maximum visibility for your research: over $100 \mathrm{M}$ website views per year

At BMC, research is always in progress.

Learn more biomedcentral.com/submissions 